\title{
Tackling the Failure of Microfinance Efforts through Amalgamating Microfinance with Charity: Two Viable Alternatives in the Context of Pakistan
}

Ashfaq Khan*.

email aak24@uow.edu.au

\begin{abstract}
The drastic shift in the microfinance paradigm during the early 1990s, when the donor community adopted a new approach as to the sustainability of microfinance institutions, changed the overall scenario of the paradigm. Instead of providing subsidized financial services to microfinance institutions (MFIs) for their life time, the donors started emphasizing self-sustainability on the part of MFIs through making them adopt principles of commercialism. The shift in the donors' approach, although relieved of their burden to a considerable extent, gave rise to an increase in the interest rates on loans for the poor. Many scholars considered it as a drift from the primary mission. This conceptual paper presents two viable alternatives which, through amalgamating microfinance and charity principles, can potentially help the sector achieve the dual objective of boosting the supply of subsidized financial resources to the sector and ensuring the poor's access to an affordable source of financial help.
\end{abstract}

Keywords: microfinance; self-sustainability; commercialism; donor community; subsidized; resources.

*Ashfaq Khan is a PhD candidate at the University of Wollongong, Australia.

\section{INTRODUCTION}

The poor in under-developed and developing countries often operate with meagre financial and non-financial resources. They can break the poverty cycle through engaging in different income-generating activities but to do that they must be provided with access to a variety of financial services. The microfinance strategy - making arrangements for providing financial services in the form of small loans to help the poor engage in small business activities and, thus, get out of the poverty web - has become a popular tool for developed nations to fight world poverty (Ledgerwood 1999). The strategy has developed over time from a simple form involving provision of small loans to poor households in rural areas to include provision of suitable training to the poor to ensure prudent utilization of the loan proceeds. Moreover, it has become renowned for its efficacy and effectiveness in terms of its success in fighting world poverty (Adams and Von Pischke 1992, Raheim 1996).

The traditional mainstream financial institutions were not willing to serve this segment of the society, nor did they command the necessary resources to meet the special financial requirements of the poor. Thus, the poor had to resort to informal sources for fulfilling their financial needs. These informal sources of finance, such as informal money lenders, used to exploit the needy poor and charge them exorbitantly high interest rates. Developed nations, therefore, felt the need for a specialized financial sector which could cater to the specific needs of the poor. Thus, microfinance was developed to provide financial services to poor households to help them start a small business and change their economic situation (Gallardo et al. 2003, Hubka and Zaidi, 2005). 
Ledgerwood (1999, p.1) defines microfinance as the provision of financial services to poor households including street vendors, small traders, small farmers, service providers (rickshaw drivers, hairdressers), artisans, and small-scale producers. Microfinance Institutions (MFIs) serve as intermediaries between the international donor community which provides subsidized financial resources to the sector and the poor recipients of the financial services. Ledgerwood (1999, p.34) names microfinance institutions development organizations because their primary objectives are to reduce poverty through creating employment opportunities for the local poor, help existing small businesses grow, and empower women through the provision of financial services.

These microfinance institutions are very much part of the local culture because their operations are limited to a particular locality. Over years of operating in a closed-knit community, these institutions become an integral part of it and share its cultural values. Thus, they have both social and economic dimensions (Meyer and Rowan 1977, Chaves and Gonzalez-Vega 1996, Oliver 1997). The Grameen Bank - one of the pioneers in the field, is a classic representation of these institutions, began its operation in 1976. The Grameen Bank has been a major success story in Bangladesh and its model has been replicated by numerous microfinance institutions across the globe.

\section{BACKGROUND}

Keeping in view the amount of subsidized financial resources being poured into the sector and the limited success achieved in terms of poverty eradication around the world, a major portion of the literature on microfinance has been devoted to the performance related aspects of microfinance institutions particularly since the mid-1990s (e.g., Remenyi and Quinones 2000, Conning 1999, Remenyi 1991, Hashemi et al. 1996, Khandker 1996, Hulme and Mosley 1996a, 1996b). The achievement of a good performance in terms of both return on investment and the number of poor households served on a sustainable basis reflect on the success of a microfinance institution. Different studies, since the 1990s, assessed the performance of microfinance institutions operating in a variety of social and cultural contexts using different analytical tools and the performance criteria discussed above (e.g., Yaron 1994, Chaves and Gonzalez-Vega 1996). Dreze and Sen (1991) studied poverty issues in some developing countries and urged policy makers not to treat all the poor alike. They suggested in their book that the poor are all different in their behaviour and, as such need different financial services to overcome their poverty. They need a variety of financial services, not just credit, to fight poverty (Dreze and Sen 1991).

Looking at the performance and success of microfinance institutions from the view point of Institutional Theory, DiMaggio and Powell (1983) and Meyer and Rowan (1977) argue that an organization can ensure its success and long-term survival if it practically proves that all its policies and procedures conform to the prevalent local social values and the outcome of its overall operations in terms of benefits to the local community meet the society's expectations. By ensuring all this the organization achieves a sustainable and legitimate status in the eyes of general public and is deemed to be eligible for the society's scarce available resources.

The literature on microfinance suggests that microfinance institutions (MFIs) will only be regarded as successful if they meet the needs of the target poor they are designed and formulated to help or, in other words, if they achieve their primary objective of eradicating poverty (Snow 1999). Thus, to ensure its survival in the long-run, a microfinance institution not only has to comply with the local rules and regulations applicable to its operations and meet society's expectations but also ensure the accomplishment of its primary objectives in 
terms of reaching highest possible number of poor households and diminishing poverty in its area of operations. By doing so, it demonstrates its legitimate existence to the society and also proves itself to be a legitimate recipient of financial and non-financial resources allocated to the sector (Snow 1999).

\subsection{The Debate About The Success Of The Existing Microfinance Efforts}

Keeping in view the level of the world poverty, the literature suggested that there was no evidence of overall success of microfinance institutions (MFIs) in terms of eradicating poverty using subsidized financial resources provided by the international donor community (Rhyne and Otero 1994). Many microfinance institutions, while trying to secure their position, impose a condition of providing some assets as collateral on the poor borrowers. This apparently excludes the main category of poor households - the poor in the 'extreme poor' category, for whom the formal microfinance effort was originally initiated, as this category of the poor normally do not possess any assets acceptable as collateral. In the case of Bangladesh, for instance, microfinance institutions have been potentially excluding many of the deserving poor households. The overall outreach of MFIs in the country in terms of reaching the number of poor in the 'extreme poor' category can be ascertained from the fact that only about 25 percent of all the clients of all microfinance institutions can be grouped as 'extreme poor' (Morduch 1999). Thus, microfinance institutions cannot claim success in terms of the achievement of their primary objective of eradicating world poverty (Christen and McDonald 1998).

Braverman and Huppi (1991) and Morduch (1999) also condemned microfinance institutions for their apparent failure to accomplish their original objective of helping the poorest of the poor, thereby eradicating poverty. Zaman's (1999) findings also endorse the fact that the microfinance sector did not fulfill its promise of eradicating world poverty. $\mathrm{He}$ studied the effects of the microfinance operations of the BRAC - a prominent microcredit provider in Bangladesh, on the overall level of poverty in the areas of its operations. He did praise the MFI's contribution to poverty reduction in the region but claimed, at the same time, that its success was not unconditional. Zaman (1999) concluded that the positive impact of the program was conditional on two factors: first, the size of the loans, as the increase in income of the poor recipients of the BRAC's loans varied substantially from borrower to borrower depending on the size of loan sanctioned to each borrower and, second, the level of poverty of the household at the time of receiving loan. Similarly, Servon and Bates (1998) argued that performance of small business enterprises could be enhanced if a bigger amount of capital is invested to start with. They found a positive correlation between a small business's performance in terms of profitability and the size of capital initially invested to start the business.

The success of the microfinance effort can be looked at both from the microfinance institutions' perspective and the borrowers' perspective.

\subsubsection{From The Microfinance Institutions’ Perspective}

The primary purpose of microfinance is to provide loans to poor people at an affordable interest rate in an attempt to enable them to get out of the poverty in which they are entangled. However, after the paradigm shift during the period from the early to mid-1990s when international donor community changed its thinking and approach as to the long-term survival and sustainability of microfinance institutions ${ }^{1}$, microfinance institutions not only

\footnotetext{
${ }^{1}$ Under the new microfinance paradigm, microfinance institutions not only have to reach maximum number of poor households with their services but also ensure their long-term survival through adopting principles of
} 
have to strive to accomplish their primary objective but also keep their other stakeholders happy and content (Dichter 1996, Rogaly 1996, Robinson 2001, 2002, Fernando 2006, Yaron 1994, Baydas et al. 1997, CGAP 1996). Thus, MFIs have to show profits to prove that their existence is not at the expense of their stakeholders - the donor community, the MFIs' staff, and the society in general. To be considered successful, therefore, microfinance institutions have to serve the poor and, through effective cost control policies, provide an acceptable return on investment (Rhyne and Otero 1994, Christen and McDonald 1998, Megicks et al. 2005). This will enable them to gain the confidence of the poor as well as other stakeholders which, in turn, will boost their chances of attaining long-term sustainability and success (Schreiner 2002, Megicks et al. 2005).

\subsubsection{From The Borrowers' Perspective}

The success of MFIs can also be looked at from the borrowers' perspective. The literature on the performance related aspects of MFIs suggests that their success in terms of accomplishment of their intertwined objectives of poverty eradication and self-sustainability is still not ascertained. Some researchers claim these institutions to have been successful in eradicating poverty (Kloppenburg 2006, Khandker and Shahidur 1998); on the other hand there is also some research, which concludes that the effort has had minimal impact on poverty eradication (Morduch 1998).

While studying the poverty and famine issues in India and Africa, Dreze and Sen (1991) concluded that the poor all over the world were not alike in dealing with their poverty issues. They adopted different complex strategies to fight poverty and manage their available financial resources according to their peculiar circumstances. The scholars conceded in their book that due to this heterogeneous behaviour they are very unlikely to be brought out of poverty using a single credit-dominated financial strategy. They rather need a variety of tailormade financial services to fit into their specific circumstances (Dreze and Sen 1991).

Before the 1990s microfinance was believed to be reaching the deserving poor. Later on, however, evidence did not endorse this thinking. In the case of Bangladesh - the original hub of formal microfinance, for instance, researchers concluded that many of the microfinance institutions were not serving the poor in the 'extreme poor' category. A study by the BRAC's Research and Evaluation Division (RED) analysed the performance of its Rural Development Programs (RDPs). It revealed that about 41 percent of the most deserving poor were not covered by any of the microfinance programs (Hasan 2003, Matin 2001). The study pointed to the apparent failure of these programs to serve the extreme poor who were the main target of microfinance. Few MFIs were incorporating innovative approaches to strengthen their operations and achieve their ultimate objective of fighting poverty by covering the really deserving extreme poor under their umbrella. While the ultimate objective of all microfinance efforts was to reach the poorest of the poor, the overall outcome was not encouraging, and the extreme poor were not given due access to financial services (Hasan 2003).

\section{THE OUTCOME OF THE PARADIGM SHIFT}

This failure on the part of formal microfinance institutions to reach the extreme poor necessitated innovations in the field to overcome the existing short-comings and making it lucrative for all levels of the poor. With the paradigm shift in the sector, microfinance

commercialism, gearing their operations towards profitability, and implementing an effective cost control mechanism. Thus, although, the international donor community did not stop providing subsidized financial resources altogether, there was a clear warning to microfinance institutions not to expect a continuous flow of subsidized financial resources throughout their existence. 
institutions have to struggle with not only reaching the poorest of the poor but also providing enough resources for ensuring their self-sustainability in the long-run. Thus, two alternatives that these institutions are left with under the changed circumstances are: first, charge an interest rate on their loans high enough to cover their operational and administrative costs, including bad loan losses, and also provide a steady rate of return on their investments and, second, take all possible steps to keep their costs at a minimum possible level (Conning 1999). The poor want continuous support in the form of subsidized financial services and it is not possible for the donor community to continue extending subsidized financial resources to the sector. After the introduction of commercialism to the sector, the stress is more on pursuing sustainability through lowering organisational costs and raising interest rates (Rhyne and Otero 1994, Christen and McDonald 1998). Rao (2003, p. 53) asserts that:

...the main objective of microcredit schemes is to provide sustainable microfinance with economic development goals. If credit lending institutions can operate profitably and efficiently by targeting lending priorities for the asset-poor in order to elevate the economic status of such borrowers (often to remain above applicable poverty line) and without dependence on any significant financial subsidies, then the microfinance scheme may be deemed to operate as a sustainable microfinance.

The literature suggests that many of the MFIs do not fit into the new definition of successful microfinance institutions, which entails serving the poorest of the poor in large numbers as well as showing profits from operations (Morduch 1999, Short 2000). The poor expect to pay an interest rate on their loans which is normally insufficient to cover all of the MFIs' costs. Thus, expenses surpass revenues and they remain financially dependent on the donor community (Morduch 1999). Their financial products are not market-driven and do not meet the specific requirements of the poor which hampers their outreach (Megicks et al. 2005). The few MFIs that have been judged as successful have achieved that status because they were almost financially self-sufficient (Schreiner 2002).

The analysis of this situation reveals that there is a contradiction between the ultimate objectives of these institutions and those of the poor. The struggle of MFIs to earn profits and thus ensure their long-term survival proves to be in conflict with the objectives of the poor to secure cheap financial assistance and help themselves to get out of poverty. Since these institutions mostly provide services in remote rural areas and deal in very small amounts, their transaction cost per borrower is normally very high. In order to cover their costs and also provide a steady return on their investments, these institutions must charge higher than the market interest rate, thus, shifting the costs to the already highly vulnerable poor households. Apparently such a high interest rate for them would be beyond their means (Khandkar 1996).

\section{MICROFINANCE EFFORTS IN PAKISTAN - ANOVERVIEW}

\subsection{Background}

The idea of microfinance is not new in Pakistan. The origin of the government's efforts in the form of many subsidized microcredit ${ }^{2}$ services, particularly in the agriculture

\footnotetext{
${ }^{2}$ The term 'microcredit', as opposed to 'microfinance', is deliberately used here to refer to the initial poverty eradication efforts when the sector was mainly dealing in small loans for the poor. The term 'microfinance' gradually replaced the term 'microcredit' in the literature when the sector started providing a wide range of financial services to the poor in addition to extending small loans.
} 
sector can be traced back to the 1960s. In addition, many Non-Governmental Organizations (NGOs) and financial institutions have been involved in providing these services in rural and urban areas for many years now. The Orangi Pilot Project (OPP) in Karachi and the Health and Nutrition Development Society (HANDS) in the Hyderabad and Thatta districts have been offering microfinance services for more than a decade (Rehman 2002).

The initiation of a formal form of microfinance efforts was witnessed during the early 1980s when the Orangi Pilot Project (OPP) was established in the country's largest city, Karachi. This was followed by the launch of the Aga Khan Rural Support Program (AKRSP) as a private sector rural development program in 1982, which later on established itself as the most reputable microfinance model in Pakistan. When compared with the Non-Governmental Organizations sector, the AKRSP's microfinance wing accounts for around 70 percent of total microfinance coverage in the country in terms of number of poor households served (CGAP 2006, p.6).

Until the early 1990s, Pakistan's microfinance sector, as in most other countries, provided mainly microcredit services. In other words, the modus operandi of the microfinance providers was to secure subsidized financial resources from international donor agencies and extend cheap/subsidized loans in small amounts to poor households with a view to help them start a small business and thus change their social status. During the 1990s, with the paradigm shift in the sector, many NGOs began providing their poor clients with a variety of financial and non-financial services, not just microcredit. The 'Kashf Foundation' and the 'Asasah', present a picture of the sector's changed external circumstances. These Non-governmental Organizations were established in the private sector in 1996 and 2003 respectively and operate under the new 'commercial microfinance' paradigm. Their focus is not only on providing a range of financial services to the country's poor but also on ensuring their own self-sustainability through a high emphasis on cost control and profitability in all aspects of their operations (CGAP 2006).

\subsection{Demand For And Supply Of Microfinance Services In The Country}

Pointing to the huge demand for microfinance services in the country, the Asian Development Bank's Microfinance Sector Development Review ${ }^{3}$ asserted that the potential demand for the services in terms of the number of poor households was approximately 6.5 million. The sector's services were in high demand while the supply was struggling to cope with the demand (ADB 2000, GoP 2003). According to the Pakistan Microfinance Network (PMN), as of June 2004, the total coverage of all the microfinance institutions was about 718,000 in terms of active microfinance clients. This was about 12 percent of the potential target of 6.5 million. These poor borrowers owed about US\$ 99 million in unpaid liabilities in respect of their loans (PMN 2004). This showed the number of unserved potential microfinance clients in the country and the need for concrete efforts to make microfinance a more effective tool to tackle the level of poverty in the country (CGAP 2006).

Realizing the fact that the resources available to the microfinance sector are not unlimited and to meet the potential demand for the services, the government of Pakistan pinpointed in its Poverty Reduction Strategy Paper of 2003 that private sector investment is crucial. It cited the Pakistan Poverty Alleviation Fund as a classic example of public-private partnership in the microfinance sector (GoP 2003, APPC 2007). The Government of Pakistan asserts that the Fund, which has operations in 87 districts of the country, operates on

\footnotetext{
${ }^{3}$ Report and Recommendation of the President to the Board of Directors on the proposed loan to the Islamic Republic of Pakistan for the Microfinance Sector Development Program (November 2000).
} 
innovative grounds, and it does not rely on simply extending micro loans. It operates from three windows: first, it has a Credit and Enterprise Development unit which provides financial assistance in the form of a credit line to microfinance institutions for the purpose of the expansion of their microfinance operations, second, it has a Community and Infrastructure unit which extends financial assistance on a cost sharing basis for physical infrastructure development within a community, and third, it has a Human and Institutional unit which gives financial assistance to its partner organizations for institutional capacity building (GoP 2003).

While all microfinance programs in the country currently reach about one million poor households, the government's current poverty reduction strategy aims to cover an additional two million poor households by 2010. The current high recovery rate of outstanding loans among most of the country's microfinance institutions is also encouraging and point to their enhanced capacity of reaching more poor households in the future (APPC 2007).

\subsection{Assessing Microfinance Success In Pakistan.}

The idea of assessing the performance of microfinance institutions at a unit level and as a whole in terms of their real impact on poverty levels has emerged relatively recently. Most of the studies on this aspect of the country's microfinance efforts were instigated after the year 2000 (Hussein and Hussain 2003). Despite the long-term association of many microfinance institutions $-\mathrm{NGOs}^{4}$, and government-sponsored rural support networks ${ }^{5}$, with the sector, according to Mr. Haroon Jamal, head of Poverty Unit at the Social Policy and Development Centre (SPDC), Karachi, poverty has actually increased (Montgomery 2005). Hari R. Lohano and Haroon Jamal of the SPDC could not confirm in their Research Report No. 48 (2003) that the microfinance efforts of the two leading microfinance schemes - the National Rural Support Program (NRSP) and the Orangi Pilot Project (OPP), did yield any long-term benefits for the country's poor; their efforts remained fruitless in terms of employment generation for the poor (Lohano and Jamal 2003). In addition, the country's microfinance ventures were still lagging far behind the total demand for microfinance services (CGAP 2006).

Keeping in view the number of potential borrowers in the microfinance sector, the cumulative coverage of the microfinance institutions has not been encouraging so far. According to a survey conducted in 2001 the outreach of the microfinance programs was limited to only 35.6 percent of the urban poor households and 16 percent of the rural. The survey concluded that almost same results were observed in the case of 'poor' and 'extremely poor' categories of the households (PNHDR 2003, Hussein and Hussain 2003). Discussing the vulnerability of the extremely poor in rural areas in the country, the Pakistan National Human Development (PNHD) report observed that landlords are in a position to easily exploit poor households. More than 52 percent of extremely poor live as tenants to big landlords putting them in a situation where the landlords can control them through slightly changing the terms and conditions of tenancy agreements. Due to inaccessibility to formal credit these poor households, being heavily dependent on the local landlords, have to borrow from them. In return, they are required to perform work for the landlords without being paid (PNHDR 2003).

\footnotetext{
${ }^{4}$ The major NGOs providing microfinance services in Pakistan are Development Action for Mobilization and Emancipation (DAMEN), Sungi Development Foundation (SUNGI), Taraqee Foundation (Taraqee), Orangi Pilot Project (OPP), Sindh Agricultural and Forestry Workers Coordinating Organization (SAFWCO), Asasah, and Kashf Foundation (Kashf) (Montgomery 2005)

${ }^{5}$ National Rural Support Program (NRSP), Punjab Rural Support Program (PRSP), Sarhad Rural Support Program (SRSP), and Thardeep Rural Development Program (TRDP) (Montgomery 2005).
} 
The literature suggests that some factors depicting good performance on the part of microfinance institutions may not always prove to be true indicators of their performance. For instance, performance indicators such as high rates of repayment of loans among borrowers and the sanctioning of additional loans have been used by many microfinance institutions in Pakistan and Bangladesh to portray their own performances as a success in terms of poverty eradication (Montgomery and Weiss 2003, Hussein and Hussain 2003). In general, loan repayments by the poor borrowers and in turn larger loan disbursements by microfinance institutions are considered to be a reflection of good performance on the part of MFIs (Yaron 1997). Loan portfolios at many microfinance programs in Pakistan such as The Bank of Khyber, The First Microfinance Bank Limited (FMFBL), the National Rural Support Programme (NRSP), and the Punjab Rural Support Programme (PRSP) were growing and the loan amounts were being well circulated between these institutions and their respective clients. Therefore, these programs were considered to be successful in terms of poverty eradication (Hussein and Hussain 2003).

The assumptions about the performance of microfinance institutions in terms of making their programs fruitful for the poor in real terms have changed. The donor community now is interested in the reliable assessment of these institutions' performance. 'Repayment' of loans on the part of borrowers, although very important for the long-term sustainability of microfinance institutions, is no longer recognized as a reliable indicator of the success of a microfinance program in terms of its impact on poverty eradication. The repayment of a loan by a borrower according to a pre-determined schedule does not necessarily mean that the loan amount has been put to its optimal use in profitable ventures and that the flow of income is from the business ventures in which the proceeds of loans were invested (Zafar and Abid 1999, Hussein and Hussain 2003, Lohano and Jamal 2003).

Thus, it makes sense that if the amount to repay a microfinance loan is coming from a source other than the small business venture of the poor borrower, then although the microfinance program's performance in terms of its own figures in the financial statements may look encouraging, yet its success in terms of poverty eradication becomes questionable. The Kashf Foundation is an example of such a success. The MFI is being run on a commercial for-profit basis and cost control in operations and loan recoveries are highly emphasized. The terms and conditions of the loan agreement make it obligatory for its borrowers to repay on time even if the poor borrowers have to resort to avenues other than their business activity where the proceeds of the loan were invested (Hussein and Hussain 2003). The situation suggests that drastic changes need to be introduced to the sector, which needs to resort to innovations in the products being offered as well as the approach being followed. The country's financial as well as non-financial resources are limited and research needs to be conducted to identify and implement suitable projects to put them to an optimal level of benefit (Rehman 2002).

\section{ISLAM'S VIEWPOINT ON POVERTY ERADICATION}

In a predominantly Muslim country like Pakistan, microfinance is not the only means of helping the poor. The third basic pillar in Islam is the payment of obligatory tax called Zakat by affluent Muslims to the eligible poor. It is the only compulsory financial obligation on Muslims which they must pay once every year on their possessions of cash and other assets. Different rates of payment apply to different kinds of assets such as cash, investments, harvest, and livestock (Dean and Khan 1997). 
The word Zakat is Arabic word which means 'purity'. An effective implementation of a Zakat system in a country provides a reliable source to protect the poor socially as well as morally (Ahmad 1991). The compulsion of payment of the Zakat distinguishes it from a charity which any one can pay to the poor voluntarily and at any time of their own will (Dean and Khan 1997). One of the purposes of making the payment of Zakat a compulsory duty on Muslims is to redistribute wealth within a society. In other words, Zakat ensures the circulation of wealth and the promotion of opportunities for the social betterment of the poor (Ahmad 1952). The rule of Zakat is not enforced by coercion, but through convincing Muslims to accept it as a moral obligation to help their poor counterparts in providing them with the means for a basic livelihood, and to pay it giving the neediest poor a priority (Hussain 1947, Dean and Khan 1997). Zakat brings the poor and the rich closer to each other and thus promotes a sense of love between them (Ali 1993, p. 88).

Thus, in a Muslim country, Zakat serves as a timely relief from financial difficulties for the poor population of the country. Particularly for that segment of the poor which self-exclude from microfinance programs on religious grounds or for some other reasons, as discussed in the following sections, Zakat can prove to be the biggest timely financial aid if collected from the wealthy and distributed to the poor according to the procedures prescribed in Islam (Dean and Khan 1997).

\section{RESEARCH ISSUES AND PROPOSED FRAMEWORKS}

\subsection{The Limited Success and Outreach of Microfinance Services}

The ultimate purpose of all microfinance programs around the world is to reach maximum number of the poor with a variety of tailor-made financial services and help them to start a small business and thus get out of the poverty web. As discussed above the success of microfinance programs in terms of serving the extreme poor, not just the poor, has been vigorously questioned in the literature. Particularly, after the paradigm shift during the early 1990 s, the issue of charging a higher interest rate by microfinance institutions on their loans, to cover their administrative and operational costs and provide for their profitability and longterm survival as well, has become an issue of debate among scholars.

In addition, the literature also suggests that two categories of the poor usually selfexclude from most microfinance programs resulting in a limited outreach of these programs in terms of serving maximum number of poor households. The first category comprise of those poor households who self-exclude from these programs on the basis of their religious beliefs. For instance, Pakistan is predominantly a Muslim country and, in Islam, the charging and paying of interest is strictly prohibited. Thus, many Muslim poor households, who are otherwise very much eligible to benefit from microfinance programs, choose not to participate in these programs because of the 'interest' factor (Choudhury and Malik 1992). The second category is made up of those poor households who think they might not be able to bear the burden of paying back their loans along with the high interest rate and thus opt to exclude themselves from the programs (Khandkar 1996, Yaron 1997).

\subsection{The Non-Productive Use Of The Zakat And Other Charity Funds.}

Although the payment of Zakat is a compulsory duty on Muslims from a religious point of view, its non-payment is not penalized by the state. Muslims pay it voluntarily depending on their individual conscience. In several predominantly Muslim countries, concerned government agencies collect Zakat through the country's internal banking channels and distribute it among the poor through a system involving an intermediary organization. In 
Pakistan Zakat is collected every year under a similar system of Zakat collection and distribution (Dean and Khan 1997).

Every year huge sums of money are collected as Zakat and distributed among the eligible poor in the country. In 2007-2008 financial year, for instance, Zakat funds to the tune of Pak rupees 4364.190 million were collected for distribution to the poor ${ }^{6}$. The amount is distributed every year among poor households and is consumed by them mostly in nonproductive avenues; there is no evidence of the poor been relieved of their plight on a more permanent basis.

\subsection{The Proposed Frameworks.}

One of the reasons for the limited success and outreach of microfinance programs around the world, which also contributed to the aforementioned paradigm shift in the sector, is the scarcity of subsidized financial resources at the disposal of international donor agencies. There is a huge gap between the demand for and supply of subsidized financial resources in the sector and the donor community cannot be expected to keep on providing subsidized financial resources to the sector without fail.

This gap can be filled to a large extent if the large sums of Zakat, and other funds available at the disposal of charitable/not-for-profit organizations around the world, collected every year and distributed among poor households and consumed by them mostly in nonproductive activities, are distributed to the economically active poor through the existing microfinance channels. The author proposes two frameworks for the implementation of such a program. The frameworks are meant to complement each other with the ultimate objective of making good use of charity funds available at the disposal of charitable organizations around the world.

In the case of predominantly non-Muslim countries, charity funds may be distributed to the poor under the principles of charity (i.e. neither principal amount nor any interest thereon will be collected back from the recipient) but backed by the general principles of microfinance (i.e. the amount given should be reasonable in size to enable the recipient to embark upon a small business endeavour, the amount must be utilized in a productive business activity, the poor recipients of funds must be imparted training and their activities must be monitored, etc.). Thus, instead of wasting ${ }^{7}$ huge funds collected under Zakat and charity by letting the poor use them for meeting their immediate consumption needs, the funds will be put to productive use, which will economically rehabilitate the poor on a longterm basis.

In the case of predominantly Muslim countries, Zakat and charity funds may be distributed to the poor and the repayment governed by the principles of Islamic banking. Thus, under the proposed framework, funds may be distributed to the economically active poor in form of small loans under the microfinance rules but the repayment of the principal amount along with profit by the poor recipient will be made under the guidelines of the Islamic commercial banking (i.e. based on profit and loss sharing basis). If the poor borrower was able to put the funds to a successful use and earns a profit, the creditor will be entitled to a share of the profits. Alternatively, in the case of a loss to the poor recipient of loan, the loss will be shared by the creditor on terms and conditions originally agreed upon between them.

\footnotetext{
${ }^{6}$ Data available on the Web site of the Ministry of Religious Affairs, Zakat, and Ushr, Government of Pakistan. ${ }^{7}$ The author used the word 'wasting' in the sense that the charity funds given to the poor are consumed in nonproductive avenues and they remain in need of financial help on a continuing basis.
} 
Since the poor do not have to pay back the amount they receive as Zakat or charity, the proceeds are usually consumed by the poor in meeting their day-to-day consumption requirements without any long-term benefits for the poor. Therefore, a prudent centrally controlled system for the efficient utilization of these funds, which may amalgamate the rules of the modern microfinance (with the exception of the 'interest' factor, of course) with those of management of charity funds, needs to be established and implemented at the government level. Under the system, establishing a priority list of all the poor, comparatively larger amounts may be given to the most deserving poor, starting with the one on the top of the list, along with expert advice and necessary training to utilize the money in some productive way instead of consuming it straightaway in non-productive ways. The amount should be large enough to help the poor start a small business. The expenses of such as system may be met by the government from the same Zakat or charity funds.

The proposed system is a new and unique idea which needs to be researched thoroughly and developed through implementing a strategy of 'learning through experience' and analysed on a long-term basis ${ }^{8}$. Apparently it has the capacity to revolutionise the microfinance world. In the short-run, it is bound to relieve the burden of international donor community which has been struggling over the years to meet the financial needs of the sector in the form of providing subsidized financial resources. In addition it is expected to reduce the burden of high interest rates on the poor's shoulders, which has become even heavier in recent years particularly after the paradigm shift in the sector as discussed above.

\section{EXPECTED OUTCOMES OF THE PROPOSED FRAMEWORKS}

Prudent implementation and rigorous follow-up of the proposed frameworks is expected to meet the following objectives with long-term benefits to the poor households and the donor community as well.

- To put Zakat and other charity funds to their optimal use, thus, saving them from being wasted, without long-term positive outcomes for the poor.

- To complement the efforts of the international donor community by ensuring their access to additional sources of subsidized funds ${ }^{9}$.

- To economically rehabilitate the poor on a long-term basis instead of helping them financially with only a shot-term relief.

- To help the poor graduate both economically and socially, instead of remaining dependent on the Zakat and/or charity stipends throughout their lives.

- To increase the outreach of existing microfinance institutions through ensuring participation of those poor households who self-exclude from these programs because of the 'interest' factor and other concerns as discussed above.

- To decrease the administrative and operational costs of the of the concerned government organizations which manage Zakat funds, thus, leaving additional funds for helping the poor.

- To reduce the burden of paying high interest rates on their small loans by the poor and thus revive the fast depleting original microfinance sector's 'social service' objective.

\footnotetext{
${ }^{8}$ The author intends to do a case study on the proposed frameworks at a later stage. He has already sent a proposal in this regard to the State Bank of Pakistan, the central bank of Pakistan, which regulates the country's financial sector.

${ }^{9}$ In the case of non-Muslim communities, charity funds collected and distributed by many not-for-profit organizations may be utilized under the proposed frameworks with the said objectives.
} 


\section{CONCLUSION.}

The demand for microfinance services around the world has increased over the past years and the success of microfinance institutions rigorously questioned by scholars. To meet the sector's huge demand for subsidized financial resources the international donor community need to explore alternative sources of funds to finance their operations. For that very purpose, during the mid-1990s, they adapted their approach from providing subsidized financial resources to microfinance institutions for their life time to emphasizing selfsustainability on their part, thus, making them more business-oriented. This shift in donors' approach, however, caused an increase in the interest rate charged by microfinance institutions from the poor on their small loans and many scholars termed it as a drift in the sector's main mission of serving the poor and helping them to get out of poverty.

The proposed frameworks are expected to have dual effect. On one hand they are expected to ensure donors' access to additional sources of low-cost funds and, on the other hand, they are expected to facilitate the poor's access to even cheaper sources of funds. To ascertain the success and analyse the pros and cons of the proposed frameworks, the programs need to be implemented on a 'pilot' basis. They should be instigated and followed upon by a local microfinance institution utilizing its existing tangible and non-tangible facilities. A limited number of economically active poor households should be selected and passed through the proposed frameworks with the selection of prospective borrowers, preparation of feasibility report on the proposed utilization of funds or sanctioning of loans, utilization of loans by the poor recipients, and collection of the data regarding the success/failure of their small business ventures closely monitored and analysed.

Theoretically speaking, keeping in view the aforementioned discussion and the existing state of the microfinance sector, with donors crying for more and more sources of subsidized funds and the poor recipients of small loans under the programs complaining about the high interest rates being charged on their loans, the author has a viable case to implement and follow. The proposed frameworks are bound to meet success if prudently financed and vigorously followed under the surveillance of professional and goal-oriented people. They, after being backed by practical results and positive outcomes, can be extended to all microfinance institutions around the world particularly in countries where charitable organizations operate in large numbers with considerable amount of charitable funds at their disposal.

\section{REFERENCES:}

Adams, DW \& Von Pischke, JD 1992, 'Microenterprise Credit Programs: De'ja vu', World Development, vol. 20, no. 10, pp. 1463-1470. https://doi.org/10.1016/0305-750X(92)90066-5

ADB 2000, 'Finance for the Poor: Microfinance Development Strategy', Asian Development Bank, Manila.

Ahmad, M 1952, Economics of Islam, Sh. Muhammad Ashraf Press, Lahore.

Ahmad, Z 1991, Islam, Poverty, and Income Distribution, The Islamic Foundation, Leicester.

Ali, S 1993, Social and Economic Aspects of the Islam of Mohammad, Edwin Mellen Press, New York.

Associated Press of Pakistan Corporation 2007, 'PM Approves Strategy to Expand Microfinance Outreach to 3 mln Households', Islamabad, 14 February.

Baydas, M, Graham, D \& Valenzuela, L 1997, 'Commercial Banks in Microfinance: New Actors in the Microfinance World', Microenterprise Best Practices Project, USAID. Development Alternatives, Inc, Bethesda, Maryland. 
Braverman, A \& Huppi, M (1991), 'Improving rural finance in developing countries', Finance and Development, vol. 21, no. 1, pp. 42-44.

CGAP 1996, 'Microcredit Interest Rates', Donor Brief No. 1, February, The World Bank, Washington, D.C. CGAP 2006, 'Performance and Transparency: A Survey of Microfinance Institutions in South Asia', Microfinance Information Exchange, Inc., The World Bank, Washington, D.C.

Chaves, RA \& Gonzales-Vega, C (1996), 'The Design of Unsuccessful Rural Financial Intermediaries: Evidence from Indonesia', World Development, vol. 24, no. 1, pp. 65-78.

https://doi.org/10.1016/0305-750X(95)00114-R

Choudhury, MA \& Malik, UA 1992, The Foundation of Islamic Political Economy, MacMillan \& Co, London.

https://doi.org/10.1007/978-1-349-21973-5

Christen, RP \& McDonald, J 1998, The microfinance bulletin, Vol. II, The Economics Institute, Boulder.

Conning, J 1999, 'Outreach, Sustainability and Leverage in Monitored and Peer-monitored Lending', Journal of Development Economics, vol. 60, pp. 51-77. https://doi.org/10.1016/S0304-3878(99)00036-X

Dean, H \& Khan, Z 1997, 'Muslim Perspectives on Welfare', Journal of Social Policy, vol. 26, no. 2, pp. 193 209. https://doi.org/10.1017/S0047279497004972

Dichter, TW 1996, 'Questioning the Future of NGOs in Microfinance', Journal of International Development, vol. 8, no. 2, pp. 259-269.

https://doi.org/10.1002/(SICI)1099-1328(199603)8:2<259::AID-JID377>3.3.CO;2-Z

DiMaggio, PJ \& Powell, WW 1983, 'The Iron Cage Revisited: Institutional somorphism and Collective

Rationality in Organizational Fields', American Sociological Review, vol. 48, pp. 147-160.

https://doi.org/10.2307/2095101

Dreze, J \& Sen, A 1991, Hunger and Public Action, Oxford University Press, Oxford, UK. https://doi.org/10.1093/0198283652.001.0001

Fernando, JL 2006, 'Microcredit and Empowerment of Women: Blurring the Boundary between Development and Capitalism', in JL Fernando (ed), Microfinance: Perils and Prospects, Routledge, New York, pp. 1-42.

Gallardo, J, Outtara, K, Randhawa, B, \& Steel, WF 2003, 'Comparative Review of Microfinance Regulatory Framework Issues in Benin, Ghana, and Tanzania', Africa Region Financial Sector Group (ARFSG), Financial Sector Operations and Policy Department, The World Bank, Washington, D.C.

Government of Pakistan 2003, 'Accelerating Economic Growth and Reducing Poverty: The Road Ahead', Poverty Reduction Strategy Paper, Ministry of Finance, Islamabad, Pakistan.

Hasan, M 2003, 'Implication of Financial Innovation for the Poorest of the Poor in the Rural Area: Experience from Northern Bangladesh', Journal of Microfinance, vol. 5, no. 2, pp. 56-78.

Hashemi, S, Sidney, RS \& Riley, P 1996, 'Rural credit programs and women's empowerment in Bangladesh', World Development, vol. 24, no. 4, pp. 635-653. https://doi.org/10.1016/0305-750X(95)00159-A

Hubka, A \& Zaidi, R 2005, 'Impact of Government Regulation on Microfinance'. Article prepared for the World Development Report 2005. Retrieved June 26, 2006, from http://siteresources.worldbank.org/INTWDR2005/Resources/Hubka_Zaidi_Impact_of_Government_Regulation. pdf.

Hulme, D \& Mosley, P 1996a, Finance against poverty, vol. I. Routledge, London.

Hulme, D \& Mosley, P 1996b, Finance against poverty, vol. II. Routledge, London.

Hussain, M 1947, Islam and Socialism, Sh. Muhammad Ashraf Press, Lahore.

Hussein, M \& Hussain, S 2003, 'The Impact of Microfinance on Poverty and Gender Equity: Approaches and Evidence from Pakistan’, Pakistan Microfinance Network, Islamabad, Pakistan.

Khandker, SR 1996, 'Grameen Bank: Impact, Costs, and Program Sustainability', Asian Development Review, vol. 14, no. 1, pp. 97-130.

Khandker S. R \& Shahidur, R 1998, Fighting Poverty With Microcredit - Experience in Bangladesh, Oxford University Press, Oxford.

Kloppenburg N. (2006), 'Microfinance Investment Funds: Where Wealth Creation Meets Poverty Reduction', in I. Matthaus-Maier \& JD Von Pischke (Eds), Microfinance Investment Funds: Leveraging Private Capital for Economic Growth and Poverty Reduction, Springer, Berlin, pp. 11-46. 
https://doi.org/10.1007/3-540-28071-5_1

Ledgerwood, J 1999, Microfinance Handbook: An Institutional and Financial Perspective, The World Bank, Washington, D.C. https://doi.org/10.1596/978-0-8213-4306-7

Lohano, HR \& Jamal, H 2003, 'Microfinancing: Fighting Against Poverty?', Research Report No. 48, Social Policy and Development Centre, Karachi, Pakistan.

Matin, I 2001, 'Targeted Development Program for the Extreme Poor: Experiences From BRAC's Experiments', Chronic Poverty and Development Policy Working Paper no. 2, Institute of Development Policy and Management, The University of Manchester, UK. https://doi.org/10.2139/ssrn.1754451

Megicks, P, Mishra, A \& Lean, J 2005, 'Enhancing Microfinance Outreach Through Market-Oriented New Service Development in Indian Regional Rural Banks', International Journal of Bank Marketing, vol. 23, no. 1, pp. 107-125. https://doi.org/10.1108/02652320510577393

Meyer, JW \& Rowan, B 1977, 'Institutionalized Organizations: Formal Structure as Myth and Ceremony', American Journal of Sociology, vol. 1, pp. 340-363. https://doi.org/10.1086/226550

Montgomery, H 2005, 'Serving the Poorest of the Poor: The Poverty Impact of the Khushhali Bank's Microfinance Lending in Pakistan', Retrieved May 3, 2006 from http://www.adbi.org/files/2005.09.28.book.khushhali.microfinance.study.pdf.

Montgomery, H \& Weiss, J. 2003, 'Great Expectations: Microfinance and Poverty Reduction in Asia and Latin America’, ADB Institute Research Paper no. 63, ADB, Manila.

Morduch, J 1999, 'The Microfinance Promise', Journal of Economic Literature, vol. 37, pp. 1569-1614.

Morduch, J 1998, The Microfinance Schism, Harvard University Press, Harvard University, Mimeograph.

https://doi.org/10.1257/jel.37.4.1569

Oliver, C 1997, 'The Influence of Institutional and Task Environment Relationships on Organizational Performance: The Canadian Construction Industry', Journal of Management Studies, vol. 34, no. 1, pp. 99-124. https://doi.org/10.1111/1467-6486.00044

Pakistan Microfinance Network 2004, ‘Annual Report', Pakistan Microfinance Network Secretariat, Islamabad, Pakistan.

Pakistan National Human Development Report 2003, 'Poverty, Growth and Governance', United Nations Development Programme, Oxford University Press, Karachi.

Raheim, S 1996, 'Microenterprise as an Approach for Promoting Economic Development in Social Work: Lessons from the Self-Employment Investment Demonstration', International Social Work, vol. 39, no. 1, pp. 69-82. https://doi.org/10.1177/002087289603900106

Rao, PK 2003, Development Finance, Springer, Berlin. https://doi.org/10.1007/978-3-662-06570-9

Rehman, N 2002, 'Social Impacts and Constraints of Micro-Credit in the Alleviation of Poverty: A qualitative study of the Micro-Credit Programme OPP-Orangi Charitable Trust, Karachi', Retrieved March 2, 2006 from http://nweb18.worldbank.org/SAR/sa.nsf/Attachments/Pakistan-Poverty-Assessment/\$File/Pakistan-PovertyAssessment.pdf.

Remenyi, J 1991, Where Credit is Due, ITP, London. https://doi.org/10.3362/9781780443843.000

Remenyi, J \& Quinones Jr. B (eds.) 2000, Microfinance and Poverty Alleviation: Case Studies from Asia and the Pacific, Pinter, London.

Rhyne, E \& Otero, M 1994, 'Financial Services for Microenterprises: Principles and Institutions', World Development, vol. 20, no. 11, pp. 1561-1571. https://doi.org/10.1016/0305-750X(92)90014-M

Robinson, MS 2001, The Microfinance Revolution: Sustainable Finance for the Poor, The World Bank, Washington, D. C. https://doi.org/10.1596/0-8213-4524-9

Robinson, MS 2002, The Microfinance Revolution: Lessons from Indonesia, The World Bank, Washington, D. C. https://doi.org/10.1596/0-8213-4953-8

Rogaly, B 1996, 'Micro-Finance Evangelism, 'Destitute Women', and the Hard Selling of a New Anti-Poverty Formula', Development in Practice, vol. 6, no. 2, pp. 100-112.

https://doi.org/10.1080/0961452961000157654

Schreiner, M 2002, 'Aspects of Outreach: A Framework for Discussion of the Social Benefits of Microfinance', Journal of International Development, vol. 14, pp. 591-603. https://doi.org/10.1002/jid.908

Servon, LJ \& Bates, T 1998, 'Microenterprise as an Exit Route from Poverty: Recommendations for Programs 
The Australasian Accounting Business \& Finance Journal, June, 2008. Khan: Tackling the Failure of Microfinance Efforts. Vol. 2, No.2.

and Policy Makers', Journal of Urban Affairs, vol. 20, no. 4, pp. 419-442.

https://doi.org/10.1111/j.1467-9906.1998.tb00430.x

Short, C 2000, 'Foreword', in S. Rutherford (ed), The Poor and Their Money, Oxford University Press, Delhi.

Snow, D 1999, 'Microcredit: An Institutional Development Opportunity', International Journal of Economic Development, vol. 1, no. 1, pp. 65-79.

Yaron, J 1994, 'What Makes Rural Finance Institutions Successful?', The World Bank Research Observer, vol. 9, no. 1, pp. 49-70. https://doi.org/10.1093/wbro/9.1.49

Yaron, J 1997, 'How to Assess Performance of Development Finance Institutions', in H. Schneider (ed), Microfinance for the Poor?, OECD, Paris, pp. 63-71.

Zafar, R \& Abid, S 1999, 'Impact Assessment as a Management and Policy Tool: The Social Economic Outcomes of Kashf’s Microfinance Series’, Kashf Foundation Discussion Paper Series, Discussion Paper no. 3. Kashf Foundation, Lahore.

Zaman, H 1999, 'To What Extent Do Microcredit Program Reduce Poverty and Vulnerability in Bangladesh?', World Development Report, The World Bank, Mimeo. 